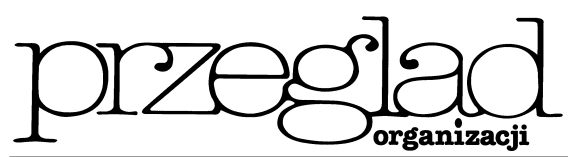

\title{
Twórczość w organizacji uczącej się - imperatyw ciągłej transgresji
}

https://doi.org/10.33141/po.2005.03.02

Przegląd Organizacji, Nr 3 (782), 2005, ss. 11-14

Paweł Szwiec

www.przegladorganizacji.pl

Towarzystwo Naukowe Organizacji i Kierownictwa (TNOiK)

\section{Wprowadzenie}

$\mathbf{T}$ ermin „organizacja ucząca się” został wprowadzony do dyskursu naukowego w 1988 roku przez R.H. Hayesa w USA i przez M. Pedlera w Wielkiej Brytanii. Przy czym samo pojęcie uczenia pojawiało się już w dziełach klasyków zarządzania $^{1)}$, a uwage przedstawicieli tej młodej dyscypliny nauki przykuło w latach 60 . i 70 . ub. w. Wówczas proces uczenia się w organizacji był przedmiotem aktywności badawczej takich uczonych, jak: H. Simon, Ch. Argyris, czy D.A. Schön ${ }^{2}$. Do jej różnorodnych efektów należy do dzisiaj inspirujacca koncepcja jedno- i dwucyklowego uczenia się ${ }^{3)}$. Współcześnie obserwujemy renesans idei organizacyjnego uczenia się ${ }^{4)}$. O ile M. Pedlerowi czy R.H. Hayesowi przypisuje się autorstwo etykiety „organizacja ucząca się”, o tyle intelektualistą najsilniej kojarzonym $\mathrm{z}$ tą koncepcją jest P. Senge. W dużej mierze wynika to z sukcesu książki jego autorstwa wydanej w 1990 roku. Biblijny charakter The Fifth Discipline. The Art and Practice of the Learning Organization oddaje ogromna liczba sprzedanych egzemplarzy, co zapewniło jej status bestseleru i miano jednej $\mathrm{z}$ najbardziej poczytnych książek biznesowych lat $90 .^{5)}$ Równiez nie bez znaczenia były działania podejmowane przez P.M. Senge'a i jego współpracowników w ramach The Center for Organizational Learning, utworzonego na fali ogromnego sukcesu książki. Jego misją był rozwój teorii i praktyki organizacji uczącej się przy aktywnym udziale, również finansowym, wiodących przedsiębiorstw6). Nieprzypadkowo została tu użyta forma czasu przeszłego - instytucja ta już nie istnieje. W związku z tym nasuwa się pytanie, czy przyczyna jej rozwiązania było wypełnienie przyjętej misji, czy też raczej rozczarowanie świata gospodarczego skutkami jej działania. Jeżeli nawet za rozwiązaniem The Center for Organizational Learning przemawiało zniechęcenie skutkami implementacji koncepcji organizacji uczącej się, to jakie czynniki powodowały, że przez całe lata 90 . uwaga wielu badaczy i praktyków ogniskowała się wokół tej tematyki? Próbując wyjaśnić fenomen popularności jakiejkolwiek koncepcji organizacji, w tym także organizacji uczącej się, należy wyjść poza czynniki kontekstowe i wziać pod uwagę treść samej koncepcji. Czym zatem jest to, co według P.M. Senge’a nie istnieje ${ }^{7)}$, a więc organizacja ucząca się? Ze względu na wieloznaczność rozważanego konstruktu trudno tu o jakieś ostateczne rozstrzygnięcia. W tej sytuacji pozostaje bądź to wybrać definicję, która z jakichś względów najbardziej nam odpowiada, bądź sformułować własną definicję, bądź też podjać próbę syntezy definicji występujacych w literaturze poprzez poszukiwanie wspólnych im elementów.

\section{Organizacja ucząca się - próba konceptualizacji}

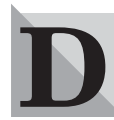
wie najczęściej przytaczane definicje organizacji uczącej się zostały sformułowane przez P.M. Senge'a i M. Pedlera. P.M. Senge rozumie organizację uczącą się jako system, w którym pracownicy nieustannie zwiększają swoje możliwości w osiąganiu pożądanych celów, kształtowane są nowe, ekspansywne wzorce myślenia, a ludzie nieustannie uczą się, jak się uczyć zespołowo ${ }^{8)}$. Natomiast M. Pedler postrzega organizację uczącą się jako układ, który umożliwia i stale wzmacnia uczenie się wszystkich jego pracowników i permanentnie przekształca się $^{9)}$. Inna znana definicja, która w odróżnieniu od wyżej przytoczonych, pomija rolę człowieka w organizacji uczącej się, charakteryzuje ją jako system zdolny do tworzenia, przyswajania i transferowania wiedzy, jak również zdolny do zmiany zachowań zgodnie z nabytą wiedzą ${ }^{10)}$. Przytoczone definicje, podobnie jak większość spotykanych w literaturze, łączy koncentracja na zmianie. Zmiana - czy to pracowników, czy samego systemu zdaje się być postrzegana jako immanentna właściwość organizacji uczącej się. Przy czym nie chodzi tu o każdą zmianę, a jedynie tę o podłożu kognitywnym, do której dochodzi w wyniku procesu uczenia się. Proces ten nie musi prowadzić do modyfikacji zachowania ${ }^{11)}$. Może natomiast, w wyniku przekształceń w zasobie posiadanej wiedzy, tworzyć jej potencjał. Jeżeli zmiana zachowania może być efektem uczenia się, a więc transformacji istniejącego zasobu wiedzy, to wyjaśnienie mechanizmów i uwarunkowań procesu uczenia się nabiera istotnego znaczenia. Tutaj nieuchronnie nasuwa się pytanie o podmiot uczenia się. Czy mogą nim być człowiek, wspólnota, czy też organizacja. O ile trudno mieć wątpliwości co do słuszności uznania jednostki za podmiot uczenia się, o tyle traktowanie grup i organizacji jako bytów uczących się budzi wiele zastrzeżeń. Natomiast jedno jest pewne, organizacja bez udziału człowieka nie zgromadzi żadnej nowej wiedzy. Dlatego w centrum zainteresowania badaczy i projektantów organizacji uczącej się zawsze powinien pozostawać człowiek. Niestety, w wyniku gromadzenia przez organizację wiedzy zatrudnionych w niej osób oraz wzajemnego dzielenia się wiedzą w systemie, może dojść do uniezależnienia się organizacji od poszczególnych pracowników. Ze względu na ten fakt, jak również powszechność downsizingu ${ }^{12)}$ oraz wysokich stóp bezrobocia pojawiają się uzasadnione wątpliwości co do możliwości wzbudzania wśród pracowników gotowości do dzielenia się posiadaną wiedzą z potencjalnymi konkurentami o obecne i przyszłe miejsca pracy. Co więcej, czy można skutecznie zachęcać pracowników do dziele- 
nia się wiedzą (ujmowaną np. w systemach eksperckich) z organizacja, w wyniku czego zwiększa się poziom prawdopodobieństwa, że staną się dla niej zbędni. Jedyną racjonalną alternatywą dla przełamania oporów przed zespołowym uczeniem się byłaby gwarancja zatrudnienia wszystkich pracowników organizacji, jak również utrzymywanie niskiego poziomu bezrobocia ${ }^{13)}$. Te postulaty pozostają jednak w sprzeczności z dominującym imperatywem techniczno-ekonomicznym i postawą skrajnego menedżeryzmu, które każą postrzegać praktyki kierownicze jedynie w kategoriach technicznych, bez uwzględniania pozaekonomicznych skutków ich stosowania.

Jeżeli pozytywnie wartościuje się uczenie w organizacji, a z doświadczenia wynika, że nie zawsze jest to uzasadnione, to istotniejsze od poznania mechanizmów procesu uczenia staje się określenie uwarunkowań jego intensywności. Innymi słowy, kluczowego znaczenia nabiera sposób, w jaki organizacje moga zwiększać częstość procesów uczenia się, bez względu na to, czy chodzi o jedno- czy też dwucyklowe uczenie się. Proces ten można zintensyfikować dzięki obfitemu czerpaniu ze wszystkich źródeł wiedzy, tj. z własnego i cudzego doświadczenia, oraz z aktywności twórczej. Jakie jednak warunki organizacyjne gwarantuja dostępność, żywotność oraz gotowość do korzystania z tych źródeł, a więc jakie właściwości powinna posiadać organizacja, którą można nazwać uczącą się? Pytając nieco inaczej, co jest warunkiem koniecznym i stymulatorem gotowości do zmiany zachowań (w) organizacji?

\section{Właściwości organizacji uczącej się}

W literaturze przedmiotu można spotkać różne propozycje dotyczące kluczowych cech organizacji uczącej się. Według P. Senge’a, do urzeczywistnienia ideału organizacji uczącej się należy dążyć poprzez praktykowanie pięciu dyscyplin: myślenia systemowego, osobistego mistrzostwa, zespołowego uczenia się, kształtowania wspólnej wizji i zmiany modeli mentalnych ${ }^{14)}$. Ich uprawianie umożliwić ma przetrwanie nie tylko organizacji, ale całego gatunku ludzkiego, któremu zagrażają trzy współcześnie dominujące zjawiska, tj. fragmentaryczność, konkurencja oraz reaktywność (adaptacyjność) ${ }^{15)}$. Bardziej praktyczną orientację przyjmuje M. Pedler, który szansę na urzeczywistnienie organizacji uczącej się upatruje w: strukturalizacji procesu formułowania strategii, jako procesu uczenia się, zapewnianiu wszystkim członkom organizacji partycypacji w procesach decyzyjnych, wykorzystywaniu technologii informatycznej w celu ułatwienia dostępu do informacji wszystkim pracownikom, funkcjonowaniu organizacji na zasadzie mechanizmu rynkowego, zróżnicowaniu systemu nagród, uelastycznieniu struktury, zaangażowaniu wszystkich pracowników organizacji $\mathrm{w}$ gromadzenie informacji dotyczących swojego otoczenia, interorganizacyjnym uczeniu się (uczenie się przez współpracę z innymi organizacjami), wspieraniu przez kadrę kierowniczą wysiłków ich podwładnych w zakresie eksperymentowania i uczenia się od innych, zapewnianiu każdemu pracownikowi środków niezbędnych do jego samorealizacji ${ }^{16)}$. O ile wielu autorów wypowiada się na temat właściwości organizacji uczącej się, o tyle nieliczni ujawniają i próbują uza- sadnić sposób, w jaki doszli do ich sformułowania. $\mathrm{Na}$ jakiej podstawie określili oni cechy środowiska organizacji stymulujące i utrwalające efektywne procesy uczenia się? W grę wchodzą tu co najmniej cztery możliwości. Po pierwsze, wykorzystanie teoretycznego dorobku nauk, w szczególności psychologii, badających nie tylko sam proces uczenia się, ale i jego kontekst. Po drugie, poszukiwanie wspólnych cech organizacji, w których albo dostrzeżono intensywne procesy uczenia się, albo zaobserwowano ich efekty w postaci elastyczności organizacji i małego oporu wobec zmian. Po trzecie, realistyczne wydaje się założenie o wystrzeganiu się jakiegokolwiek systematycznego podejścia przy formułowaniu koncepcji organizacji uczącej się lub też dokonywaniu syntezy dwóch wyżej opisanych podejść. Pierwsze, zwane dedukcyjnym, z powodzeniem może być wykorzystane do określenia mechanizmów oraz pozaorganizacyjnych determinant uczenia się pracowników. Drugie, określane mianem indukcyjnego, jest szczególnie przydatne przy identyfikacji organizacyjnych uwarunkowań uczenia się pracowników. Dlatego oba podejścia powinny być wykorzystywane $\mathrm{w}$ procesie poszukiwania właściwości organizacji uczącej się.

\section{Aktywność twórcza pracowników - warunek sprawnego funkcjonowania organizacji uczącej się}

T edną z podstawowych cech tego typu systemu jest zdolność pracowników do generowania nowej wiedzy, a więc dokonywania aktów twórczych ${ }^{17)}$. Zjawisko twórczości pozostawało na obrzeżach dyskursu intelektualnego aż do roku 1950, w którym to P. Guilford wezwał przedstawicieli nauk behawioralnych do podjęcia intensywniejszych prób zrozumienia tego fenomenu. $\mathrm{Na}$ apel odpowiedzieli również przedstawiciele nauk o organizacji i zarządzaniu, czego świadectwem pozostaja publikacje dotyczące twórczości, które ukazały się w wiodących czasopismach z tej dyscypliny. Mniej więcej od 1956 roku do początku lat 90. zainteresowanie twórczościa w organizacji pozostawało na nie zmienionym poziomie. $\mathrm{Z}$ analizy zawartości 160 wiodących anglojęzycznych czasopism z zarządzania znajdujących się w bazie Business Source Premier (BSP) wynika, że w latach 1966-1992 prawie każdego roku ukazywało się od 1 do 3 artykułów dotyczących twórczości, natomiast w sumie w latach 1993-2004 ukazało się ich 150, co daje liczbę około 15 artykułów rocznie. Co warte podkreślenia, problematyka twórczości była i jest szczególnie silnie obecna w czasopismach filadelfijskich. Wszak pierwsze artykuły o twórczości w organizacji pojawiły się w „Harvard Business Review” i „Administrative Science Quarterly”, a nie liczac specjalistycznego czasopisma „Creativity \& Innovation Management", najwięcej publikacji na zadany temat ukazało się w „Academy of Management Journal”. W latach 90. podstawowy impuls do intensyfikacji badań nad twórczościa w organizacji pochodził ze świata praktyki gospodarczej i uwarunkowany był zajściem istotnych zmian społeczno-kulturowo-ekonomicznych w otoczeniu współczesnych organizacji. Całokształt tych zmian, często określanych mianem społeczeństwa pokapitalistycznego czy gospodarki opartej na wiedzy, zwrócił uwagę teoretyków i praktyków zarządzania 
na problematykę wiedzy, uczenia się, innowacji i zmiany. Przyniosło to efekt w postaci sformułowania koncepcji organizacji uczącej się, zarządzania wiedzą, zarzadzania innowacjami i zarzadzania zmiana. Mimo że konstrukt twórczości jest ważnym elementem każdej z wymienionych koncepcji, odgrywa on szczególną rolę w skutecznym urzeczywistnianiu organizacji uczącej się. Po pierwsze, obok uczenia się poprzez doświadczenie własne i cudze oraz włączanie nowej wiedzy, jej samodzielne generowanie jest jednym ze sposobów uczenia się organizacji ${ }^{18)}$. Po drugie, zdolność organizacji do uczenia się wyznacza jej potencjał wywoływania i dostosowywania się do zmian otoczenia. Przy czym nie każda wygenerowana samodzielnie wiedza musi być twórcza. Będzie nią, z czym zgadza się większość autorów piszących na gruncie nauk o organizacji i zarządzaniu o twórczości, jedynie wiedza nosząca znamiona nowości i użyteczności dla osiągania celów organizacji ${ }^{19)}$. Z uwagi na coraz powszechniejszą świadomość roli twórczości w osiąganiu sukcesu organizacji w latach 90. podjęto kilka prób sformułowania teorii organizacyjnej twórczości. Na szczególną uwagę zasługują propozycje: R.J. Sternberga, L.A. O'Hare, T.L. Lubarta, T.M. Amabile oraz R.W. Woodmana, J.E. Sawyera, R.W. Griffina. Na podstawie twierdzeń tych teorii zidentyfikowano najważniejsze właściwości organizacji twórczej, a więc systemu szczególnie sprzyjającemu kreatywności jego pracowników.

\section{Organizacja ucząca się - organizacja twórcza}

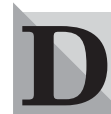

zięki takiemu zabiegowi możliwa stała się odpowiedź na pytanie, na ile właściwości systemu postulowane przez teoretyków organizacji uczącej się sprzyjają uczeniu się przez generowanie nowej i użytecznej wiedzy. Z zestawienia dokonanego w tabeli jednoznacznie wynika, że cechy organizacji uczącej się i twórczej w dużym stopniu są zbieżne. Można zatem postawić hipotezę, że środowisko organizacji uczącej się sprzyja twórczości jej pracowników. Przy czym teoretycy tej koncepcji powinni większą uwagę poświęcić wykorzystaniu procesów rekrutacji zorientowanych na pozyskanie pracowników obdarzonych dużym potencjałem twórczym, a więc posiadających znaczny zakres wiedzy eksperckiej i skłonność do innowacyjnego myślenia.

Co więcej, teoretycy tej koncepcji powinni uświadomić praktykom, jak ogromną rolę w akcie twórczym odgrywa motywacja wewnętrzna pracownika. Jej utrzymanie wymaga od kierowników ostrożnego wykorzystywania wszelkich nagród, jak również kształtowania środowiska organizacji umożliwiającego samorealizację wszystkich zatrudnionych w niej osób. I ostatnia, aczkolwiek najważniejsza kwestia, powszechnie poruszana przez środowisko teoretyków zarządzania. Warunkiem koniecznym pojawienia się nie tylko twórczości, ale również i podmiotowości pracow-

\section{Tab. Właściwości organizacji uczącej i organizacji twórczej}

\begin{tabular}{|c|c|}
\hline Or & \\
\hline $\begin{array}{l}\text { - Zaangażowanie pracowników wszystkich szczebli, party- } \\
\text { cypacja pracownicza, demokratyczny styl kierowania, sa- } \\
\text { mokontrola, decentralizacja zarządzania } \\
\text { - Ciągły rozwój i szkolenia pracowników } \\
\text { - Nagradzanie postaw kwestionujących istniejący stan } \\
\text { rzeczy, myślenia generatywnego } \\
\text { - Wizja podzielana przez wszystkich pracowników } \\
\text { - Zespołowe uczenie się, klimat otwartej komunikacji } \\
\text { i współdziałania } \\
\text { - Wykorzystywanie technik humanizacji pracy, w tym } \\
\text { grup autonomicznych } \\
\text { - Płaska, organiczna struktura organizacyjna } \\
\text { - Powszechny dostęp do informacji }\end{array}$ & $\begin{array}{l}\text { - Demokratyczny styl kierowania, partycypacja w podej- } \\
\text { mowaniu decyzji, znaczna autonomia pracowników } \\
\text { - Rozwój wiedzy eksperckiej pracowników oraz umiejętno- } \\
\text { ści technicznych } \\
\text { - Skłonność pracowników do myślenia innowacyjnego, do } \\
\text { generowania wielu rozwiązań problemów } \\
\text { - Nastawienie pracowników na współpracę, normy wspie- } \\
\text { rające swobodną wymianę idei } \\
\text { - Zróżnicowanie grup pod względem płci, światopoglądu, } \\
\text { realizowanych w organizacji zadań } \\
\text { - Organiczna struktura organizacyjna } \\
\text { - Eatwy i powszechny dostęp do wszelkiego rodzaju zaso- } \\
\text { bów niezbędnych do dokonywania aktów twórczych, w tym } \\
\text { informacji } \\
\text { - Rozwinięte umiejętności interpersonalne } \\
\text { - Poczucie bezpieczeństwa } \\
\text { - Pewni siebie pracownicy } \\
\text { - Motywacja wewnętrzna pracowników } \\
\text { - Wsparcie ze strony kierowników } \\
\text { - Podejmowanie ryzyka, uczenie się na własnych błędach }\end{array}$ \\
\hline
\end{tabular}

Źródło: opracowanie własne na podstawie: S.C. GOH, The Learning Organization: An Emperical Test of a Normative Perspective, „International Journal of Organization Theory\&Behavior”, 4 (3-4) 2001, s. 333-335; S.J. PORTH, J. McCALL, T.A. BAUSCH, Spiritual Themes of the Learning Organization, „Journal of Organizational Change Management”, 12 (3), 1999, s. 213-216; J.R. JOHNSON, Embracing Change: A Leadership Model for The Learning Organization, „International Journal of Training and Development", 2 (2), 1998, s. 144-145; A. CARR, The Learning Organization. New Lessons/Thinking for the Management of Change and Management Development?, „Journal of Management Development”, 16 (4), 1997 , s. 4; I. NONAKA, The Knowledge - Creating Company, „Harvard Business Review”, 69 (6), 1991, s. 97 - 104, P.M. SENGE, The Leader's New Work: Building Learning Organization, „Sloan Management Review”, 32 (1), 1990, s. 8-10; R.W. WOODMAN, J.E. SAWYER, R.W. GRIFFIN, Toward a Theory of Organizational Creativity, „Academy of Management Review”, 19 (2), 1993, s. 293-321; R.J. STERNBERG, L.A. O'HARA, T.I. LUBART, Creativity as Investment, „California Management Review”, 40 (1), 1997, s. 8-11; T.M. AMABILE, How to Kill Creativity, „Harvard Business Review”, 76 (5), 1998, s. 78. 
nika jest zagwarantowanie mu autonomii. Czy organizacja ucząca się, lansowana powszechnie jako propodmiotowa i humanistyczna koncepcja, stanowi zagrożenie dla wolności pracownika. Biorąc pod uwagę głosy zwolenników tej koncepcji wskazujące na konieczność tworzenia warunków umożliwiających samorealizację wydaje się, że wzrost zakresu autonomii pracownika w organizacji uczącej jest kwestią bezdyskusyjną. Czy jednak nie jest to tylko złudzenie wywołane zmianą formy kontroli, a więc zastapienia kontroli bezpośredniej pośredniąa ${ }^{20}$, sprawowaną za pomoca jakkolwiek ekspansywnych, to jednak zunifikowanych modeli mentalnych ${ }^{21}$. Przy czym owa zmiana świadomości pracowników może być ukierunkowana na kształtowanie schematów poznawczych, w których centralne miejsce zajmuje otwartość na Drugiego, uznanie jego odmienności i równości, a więc założenia charakterystyczne dla osób przyjmujących postawę dialogu ${ }^{22)}$. Zakładając, że modele te wyznaczają sposób patrzenia na świat, a więc pełnią funkcje podobne do paradygmatu, wpływ na nie nie może być totalny, ale powinien ograniczać się jedynie do kilku podstawowych kwestii, jak np. kształtowania wrażliwości systemowej, czy założeń sprzyjających przyjmowaniu postawy dialogu. W organizacji uczącej się musi pozostać przestrzeń dla sprzecznych interpretacji, twórczego napięcia, „pięknego różnienia się” i oczywiście na dialog.

Pawet Szwiec

Uniwersytet Opolski Wydział Ekonomiczny, Katedra Organizacji i Zarządzania

\section{PRZYPISY}

1) F.W. Taylor podkreślał pozytywną rolę treningu pracowników oraz eksperymentowania w rozwoju organizacji. Co więcej, uznawał zmianę stanu świadomości, tak kierowników, jak i pracowników wykonawczych, za konieczny warunek pełnego wykorzystania potencjału zarządzania naukowego; F. LUTHANS, M.J. RUBACH, P. MARSNIK, Going beyond Total Quality: The Characteristics, Techniques, and Measures of Learning Organizations, „The International Journal of Organizational Analysis”, 3 (1), 1995, s. 26.

2) F. LUTHANS, M.J. RUBACH, P. MARSNIK, Going beyond Total Quality: The Characteristics, Techniques, and Measures of Learning Organizations, ,The International Journal of Organizational Analysis”, 3, (1), 1995, s. 27.

3) Sformułowana przez P.M. Senge’a koncepcja uczenia się adaptacyjnego i twórczego (innowacyjnego, generatywnego) pod względem ideowym zbliżona jest do koncepcji uczenia się na zasadzie pojedynczej i podwójnej pętli autorstwa Ch. Argyrisa i D.A. Schöna.

4) Pierwsze publikacje na temat uczenia się organizacji ukazały się w 1969 roku. W latach 1971-1974 zainteresowanie ta problematyka pozostawało na minimalnym poziomie, by od 1975 do 1979 roku stopniowo, aczkolwiek z niewielkimi wahaniami, wzrastać. W latach 1980-1982 liczba publikacji dotyczacych tej tematyki była mniejsza w porównaniu z okresem poprzednim. Do 1989 roku utrzymywała się na nieco wyższym, ale stabilnym poziomie, aby lawinowo wzrastać od 1990 roku; M. CROSSAN, T. GUATTO, Organizational Learning Research Profile, „Journal of Organizational Change Management”, 9 (1), 1996 , s. 108.

5) A.M. JONES, C. HENDRY, The Learning Organization: Adult Learning and Organizational Transformation, „British Journal of Management", 5 (2), 1994, s. 154.

6) F. KOFMAN, P.M. SENGE, Communities of Commitment: The Heart of Learning Organizations, „Organizational Dynamics", 22 (2), 1993, s. 5.

7) Twierdzenie to, choć dla niektórych autorów bliskie herezji, wydaje się uzasadnione w świetle poglądów P.M. Senge'a na istotę organizacji uczącej się oraz na naturę rzeczywistości społecznej. Według niego organizacja uczaca się to wizja systemu idealnego, którą dopiero trzeba urzeczywistniać. To niekończąca się podróż, w której nieosiagalny cel rodzi twórcze napiecie.

8) A. MUMFORD, The Learning Organization in Review, „Industrial and Commercial Training”, 27 (1), 1995, s. 9. 9) M. PEDLER, A Guide to the Learning Organization, „Industrial and Commercial Training", 27 (4), 1995, s. 21.

10) D.A. GARVIN, Building a Learning Organization, „Harvard Business Review", 71 (4), 1993, s. 80.

11) P. G. ZIMBARDO, Psychologia $i$ zycie, Wydawnictwo Naukowe PWN, Warszawa 1999, s. 311.

12) Downsizing jest jedną $\mathrm{z}$ najpopularniejszych technik zarzadzania. W 2001 roku organizacje w USA ogłosiły plany zwolnienia prawie dwóch milionów pracowników. Tylko między 11 września 2001 roku a 1 lutego 2002 roku zwolniono około 999000 pracowników. Liczba osób zwolnionych w pierwszym kwartale 2002 r. przekroczyła o 9\% liczbę pracowników zwolnionych w pierwszym kwartale 2001 r. Redukcje dotyczyły wszystkich członków organizacji. Jak oszacował Morgan Stanley, około 80\% zwalnianych obecnie w USA to dobrze wykształceni pracownicy umysłowi. W Europie i Azji downsizing również zbiera obfite żniwo. Organizacje znajdujace sie co najmniej w dobrej sytuacji finansowej, np. Hitachi, Fujitsu, Toshiba, czy Sony dokonały znacznych redukcji personelu. Szacuje się, że w 2006 roku w Chinach straci prace przynajmniej 20 milionów ludzi. W Europie sytuacja jest zróżnicowana. Są państwa, np. Niemcy, Francja, Włochy, w których z powodu istniejacych przepisów prawnych redukcje sa kosztowne, a wiec i trudniejsze do przeprowadzenia; W.F. CASCIO, Strategies for Responsible Restructuring, „Academy of Management Executive”, 16 (3), 2002, s. 80, 83; D. Noer uważa, że ze wzgledu na dramatyczne zmiany w charakterze samej pracy, downsizing będzie częścią krajobrazu gospodarczego i codziennością organizacyjną przynajmniej przez nastepne 20 lat; D. CHAUDRON, After the Layoffs: Healing and Rebuilding, „HR Focus”, 71 (12), 1994 , s. 9.

13) A. ÖRTENBLAD, Organizational Learning: A Radical Perspective, „International Journal of Management Review", 4 (1), 2002, s. 94.

14) P.M. SENGE, Piata dyscyplina. Teoria i praktyka organizacji uczacych się, Oficyna Ekonomiczna, Kraków 2002, s. $20-25$.

15) F. KOFMAN, P.M. SENGE, Communities of Commitment: The Heart of Learning Organizations, „Organizational Dynamics" 22 (2), 1993, s. 7.

16) M. PEDLER, T. BOYDELL, J. BURGOYNE, Learning Company Project: A Report on Work Undertaken October 1987 to April 1988, The Training Agency, Sheffield, 1988, za C. LEITCH, R. HARRISON, J. BURGOYNE, C. BLANTERN, Learning Organizations: The Measurement of Company Performance, „Journal of European Industrial Training", 20 (1), 1996, s. 38.

17) J.W. Slocum, D. Lei, M.E. McGill obok takich cech pracowników organizacji uczacej się, jak: otwartość, myślenie systemowe, poczucie własnej skuteczności i empatii wymieniaja kreatywność; M.E. McGILL, J.W. SLOCUM, D. LEI, Management Practices in Learning Organizations, „Organizational Dynamics”, 21 (1), 1992, s. 12.

18) H. STEINMANN, G. SCHREYÖGG, Zarzadzanie. Podstawy kierowania przedsiebiorstwem. Koncepcje, funkcje, przyktady, Oficyna Wydawnicza Politechniki Wrocławskiej, Wrocław 1995, s. 302

19) Ö. AKIN, C. AKIN, On the Process of Creativity in Puzzles, Inventions, and Designes, „Automation in Construction", 7 (2-3), 1998, s. 123; T.M. AMABILE, R. CONTI, H. COON, J. LAZENBY, M. HERRON, Assessing the Work Environment for Creativity Academy of Management Journal”, 39 (5), 1996, s. 1155; H.A. SIMON, How Managers Express their Creativity, ,The McKinsey Quarterly", jesień 1986 , s. 68 .

20) Na konieczność zastąienia kontroli bezpośredniej kontrolä pośrednią wskazuje również P. Senge.

21) A. ÖRTENBLAD, Organizational Learning: A Radical Perspective, „International Journal of Management Review", 4 (1), 2002, s. 94.

22) S. KOWALCZYK, Z refleksji nad człowiekiem. Człowiek, społeczność, wartość, Wydawnictwo Towarzystwa Naukowego Katolickiego Uniwersytetu Lubelskiego, Lublin 1995 , s. 47. 